\title{
Angela Merkel wobec integracji Turcji z Unią Europejską w latach 2005-2015
}

Ze względu na geostrategiczne położenie Republika Turcji zajmuje szczególne miejsce w polityce zagranicznej Republiki Federalnej Niemiec oraz Europy. W żywotnym interesie Niemiec i Unii Europejskiej leży utrzymanie dobrych stosunków z tym państwem oraz zbliżenie go do Europy, aby nie ewoluowało ono w kierunku antyzachodnio nastawionych krajów islamskich. Turcja, z jednej strony, jako państwo stowarzyszone z Unią, wzmacnia europejskie poczucie bezpieczeństwa, gdyż oddziela państwa członkowskie od ogarniętego konfliktami Bliskiego Wschodu. Demokratyczny rozwój tego państwa mógłby pozytywnie oddziaływać na inne kraje regionu, jako dobry przykład godzenia demokracji z islamem (Zięba, 2010, s. 29, 31). Z drugiej strony, integracja Turcji z Unią oznacza uzyskanie wpływu przez to państwo na proces decyzyjny UE oraz, co jest szczególnie istotne w obecnej sytuacji politycznej, przesunięcie granicy organizacji w bardzo niestabilne regiony świata i migrację obywateli tureckich.

Celem artykułu jest przedstawienie stanowiska Angeli Merkel wobec członkostwa Turcji w Unii Europejskiej w latach 2005-2015. Podzielony został na 6 części, które przybliżają historię stosunków unijno-tureckich oraz najczęściej pojawiające się kwestie podejmowane przez kanclerz w związku z tureckimi staraniami o akcesję. Autorka zdaje sobie sprawę, iż nie przedstawiła całego wachlarza zagadnień związanych ze staraniami o członkostwo tegoż państwa, niemniej zarysowała ważne kwestie, które najbardziej wpłynęły na postawę A. Merkel w ostatnich 10 latach.

\section{Stosunki UE-Turcja do 2005 r.}

Pierwsze kontakty między Turcją i Europejską Wspólnotą Gospodarczą miały miejsce w latach 50-tych XX w. W 1963 r. podpisany został układ stowarzyszeniowy (tzw. porozumienie ankarskie), który w art. 28 stanowił, iż jeśli Turcja „,w pełni przyjmie na siebie obowiązki zapisane w traktacie założycielskim EWG, przez obie strony zbadana zostanie możliwość przystapienia" (Abkommen, 1964, s. 3692/64). Ponieważ prace nie przebiegały zgodnie z założonym harmonogramem, protokół dodatkowy do układu stowarzyszeniowego (tzw. protokół z Ankary) podpisany został dopiero w 1970 r. ( $A d$ ditional, 1973, s. 17-33). Następnie m.in. ze względu na bardzo niepokojącą sytuację wewnętrzną w Turcji (terroryzm, zabójstwa polityczne, przejęcie władzy przez armię w wyniku zamachu stanu), napięte stosunki grecko-tureckie (z powodu Cypru oraz przyjęcia Grecji do EWG) oraz kryzysy paliwowe, współpraca między Wspólnotą a Turcją zamarła. Zainteresowanie nią odżyło dopiero w latach 80-tych w związku ze wzrostem 
napięcia na linii Wschód-Zachód. Wykorzystując sprzyjający klimat 14 kwietnia 1987 r., w imieniu rządu tureckiego, minister ds. europejskich Ali Bozer, złożył pierwszy formalny wniosek o członkostwo. W wydanej dwa lata później negatywnej opinii Komisji WE można było przeczytać, iż Turcja nie spełnia warunków członkostwa, a nawet gdyby było inaczej, nie zostałaby przyjęta, gdyż priorytetem jest przyjęcie nowego traktatu i utworzenie Unii Europejskiej (Osiewicz, 2009, s. 188-189). Stanowisko to pokrywało się z pozycją ówczesnego zachodnioniemieckiego kanclerza - Helmuta Kohla - oraz koalicyjnego rządu (CDU/CSU-FDP), iż należy wykorzystać możliwości, które stwarza układ stowarzyszeniowy, czyli np. stworzyć unię celną (Archiv der Gegenwart, 1987, s. 30974). Mimo iż, zgodnie z postulatem RFN, Komisja - 18 grudnia 1989 r. - oraz Rada Ministrów - 5 lutego 1990 r. - zobowiązały się do przedstawienia Turcji nowych propozycji zacieśnienia współpracy gospodarczej, dopiero w 1995 r. zakończone zostały prace nad umową o unii celnej (Koszel, 2008, s. 132).

Po upadku ZSRR i komunizmu w państwach Europy Środkowo-Wschodniej rola Turcji jako strategicznego partnera uległa zdecydowanemu zmniejszeniu. Ponadto liczne problemy wewnętrzne tego państwa, które sugerowały, iż Turcja nie będzie mogła wypełnić ustalonych w 1993 r. tzw. kryteriów kopenhaskich, oraz wciąż niezbyt dobre stosunki z Grecją i Cyprem spowodowały, iż Unia skoncentrowała się na procesie rozszerzenia na Wschód. Mimo sprzeciwu Turcji, nie zdecydowano się na przyznanie jej statusu państwa kandydującego podczas szczytu w grudniu 1997 r. (Schlussfolgerungen, 1997; Osiewicz, 2009, s. 188-189). Stanowisko takie pokrywało się z ówczesnymi poglądami frakcji parlamentarnej CDU/CSU, która, wraz z koalicjantem, proponowała odrębne i uprzywilejowane traktowanie Turcji (Archiv der Gegenwart, 1997, s. 42505-06). Dopiero rok po bojkocie przez Turcję szczytu Rady Europejskiej w Cardiff, zdecydowano się uznać to państwo za kandydata do członkostwa w Unii Europejskiej. Podstawą zmiany decyzji była pozytywna opinia Komisji Europejskiej z listopada 1999 r. oraz poprawa stosunków z Grecją (1999 Regular Report, 1999).

Perspektywa akcesji stała się asumptem do wprowadzania wielu zmian politycznych i gospodarczych w Turcji, w tym m.in. do zniesienia kary śmierci, zagwarantowania przestrzegania praw człowieka (także mniejszości kurdyjskiej), swobody wypowiedzi i zgromadzeń czy równości kobiet i mężczyzn (Koszel, 2008, s. 135). Wysiłki strony tureckiej zostały docenione i wkrótce podczas posiedzenia Rady Europejskiej 16-17 grudnia 2004 r. ustalono, iż negocjacje akcesyjne rozpoczną się niecały rok później. Warunkiem było unormowanie do tego czasu stosunków turecko-cypryjskich (Konkluzje Prezydencji, 2004). Ponadto zastrzeżono, że jeżeli Turcja nie spełni unijnych wymagań, mające trwać ok. 10 lat rokowania akcesyjne będą mogły być zerwane przez każde państwo członkowskie. Ustalono także okresy przejściowe i klauzule ochronne dotyczące gospodarki. Państwom członkowskim pozostawiono wybór terminu otwarcia rynków pracy dla obywateli tureckich (Koszel, 2008, s. 134).

\section{„Uprzywilejowane partnerstwo" czy pelne czlonkostwo?}

Angela Merkel objęła urząd kanclerski na miesiąc przed planowanym rozpoczęciem negocjacji akcesyjnych z Turcją. Jako szefowa CDU wyrażała niechęć do idei 
zintegrowania tego państwa ze strukturami wspólnotowymi, stojąc na stanowisku, iż istnieją inne możliwości współpracy z tym państwem bez formalnego członkostwa, jak tzw. „uprzywilejowane partnerstwo" (Koszel, 2008, s. 136; Ondarza, 2005, s. 90-93). Fundamentem tej koncepcji było przekonanie, jasno wyrażone przez kanclerz podczas szczytu gospodarczego w Davos w 2004 r., iż pełne członkostwo Turcji nie jest możliwe, m.in. ze względu na niespełnienie kryteriów kopenhaskich, zatem należy szukać innego rozwiązania, które wychodziłoby naprzeciw jej europejskim aspiracjom (Keese, 2004). „Uprzywilejowane partnerstwo” polegać miało na zapewnieniu Turcji „ekskluzywnego" statusu przy jednoczesnym wyłączeniu jej z grona innych państw stowarzyszonych. Partnerstwo miało być czymś więcej niż unia celna. Proponowano silniej włączyć Turcję do Europejskiej Polityki Zagranicznej i Bezpieczeństwa oraz do Europejskiej Polityki Bezpieczeństwa i Obrony (udział w posiedzeniach ministrów spraw zagranicznych, uczestnictwo w tworzeniu grup bojowych). Chciano zintensyfikować współpracę między organami i instytucjami wymiaru spraw wewnętrznych, sprawiedliwości oraz służb wywiadowczych w celu zwalczania terroryzmu, ekstremizmu i przestępczości zorganizowanej (Privilegierte Partnerschaft, 2004). Ponadto zastanawiano się nad utworzeniem wspólnej Komisji i Rady UE-Turcja oraz Komisji Parlamentarnej UE-Turcja, które miałyby monitorować funkcjonowanie „uprzywilejowanego partnerstwa”. Miały być one wzorowane na strukturach i organach Europejskiego Obszaru Gospodarczego (partnerstwo nie zakładało przyjęcia tego państwa do EOG, dopuszczało możliwość włączenia go do 3 z 4 unijnych swobód, przy pewnych ułatwieniach dotyczących ruchu osobowego) (Guttenberg, 2004, s. 6-7, 15-19).

Przekonanie Merkel o słuszności „uprzywilejowanego partnerstwa” z Turcją było tak silne, iż pod koniec sierpnia 2004 r. przewodnicząca CDU wystosowała list do czołowych europejskich konserwatywnych polityków i przywódców Europejskiej Partii Ludowej z propozycją ustanowienia z Turcją ,uprzywilejowanego partnerstwa" zamiast pełnego członkostwa w UE (,,Privilegierte Partnerschaft”, 2004; Koszel, 2008, s. 137). Niezrażona porażką jeszcze w grudniu podczas debaty w Bundestagu argumentowała, że „uprzywilejowane partnerstwo” jest przemyślanym konceptem, alternatywa, która umożliwi Turcji posiadanie „unikalnych i intensywniejszych relacji z Unią Europejską". Broniąc koncepcji partnerstwa odrzucała przy tym wysuwane przez zwolenników akcesji argumenty, iż Turcja powinna stać się członkiem UE, gdyż wszystkie rządy od czasów Konrada Adenauera obiecywały jej członkostwo (trzeba mieć na uwadze okoliczności, w których te decyzje zostały podjęte, nie może obowiązywać żaden automatyzm), że przynależy politycznie i historycznie do Europy (państwo to nie leży w Europie, nie spełnia kryteriów kopenhaskich, nie podziela chęci stworzenia unii politycznej, brak w nim m.in. wolności religijnej), że należy ją przyjąć ze względu na geostrategiczne położenie (Unia nie jest globalną potęgą zapewniającą bezpieczeństwo, jest nią NATO, do którego Turcja należy), że pełni funkcję mostu pomiędzy światem chrześcijańskim i islamem oraz że Unia musi udowodnić, iż nie jest „klubem chrześcijańskim” (Turcja nie jest typowym państwem arabskim i islamskim, będzie lepiej spełniać funkcję mostu, jeśli nie będzie częścią UE) (Plenarprotokoll 15/148, 2004, s. 13783-13787).

Dopiero uformowanie rządu wielkiej koalicji CDU/CSU-SPD oraz powierzenie A. Merkel stanowiska kanclerza w 2005 r. stało się punktem zwrotnym w sposobie jej 
patrzenia na przyjęcie Turcji do UE. W umowie koalicyjnej, wspomniano o „szczególnym interesie" Republiki Federalnej Niemiec w powiązaniu tego państwa z Unią. Choć zamknięcie negocjacji akcesyjnych uznano za kwestię otwartą, przychylnie odniesiono się do ich rozpoczęcia. Podkreślano, iż proces ten wiąże się z olbrzymim wyzwaniem w aspekcie gospodarczym, demograficznym i kulturalnym zarówno dla strony tureckiej, jak i unijnej. Zatem powiązano powodzenie akcesji z wypełnianiem przez Turcję kryteriów kopenhaskich (w tym z kontynuacją demokratycznych reform) oraz ze zdolnością Unii do rozszerzenia. Zastrzeżono, że gdyby okazało się, że któraś ze stron nie jest gotowa, obowiązywać będą dotychczasowe zobowiązania (Gemeinsam, 2005; Koszel, 2008, s. 137-138).

Zgodnie z umową koalicyjną od początku $2006 \mathrm{r}$. A. Merkel wielokrotnie podkreślała, iż o dalszym poszerzeniu Unii nie może być mowy bez wcześniejszego zreformowania jej instytucji (przyjęcia Konstytucji Europejskiej, a później Traktatu reformującego UE) oraz bez wypełnienia kryteriów kopenhaskich (Regierungserklärung von Bundeskanzlerin Dr. Angela Merkel, 2006; Rede von Bundeskanzlerin Dr. Angela Merkel zur Eröffnung des Türkisch, 2006). Stanowisko to było zakorzenione w przekonaniu, iż jednoczesne rozszerzanie i pogłębianie Unii Europejskiej skazane jest na niepowodzenie (Rede von Bundeskanzlerin Dr. Angela Merkel zur Eröffnung des Internationalen, 2006). Nie oznaczało jednakże chęci całkowitego zamrożenia procesu. Podczas październikowej wizyty w Stambule i Ankarze Merkel publicznie oświadczyła, że jako kanclerz będzie kontynuowała rozmowy dotyczące akcesji Turcji do UE, choć jako przewodnicząca partii faworyzowała "uprzywilejowane partnerstwo". Zmianę swojego stanowiska motywowała obowiązującą niemiecki rząd zasadą pacta sunt servanda (EU-Beitrittsverhandlungen, 2006). Nawet w związku z przedłużającym się zamknięciem tureckich portów i lotnisk dla statków i samolotów cypryjskich Merkel opowiadała się za częściowym, a nie całkowitym zawieszeniem negocjacji z Ankarą (Türkei-Verhandlungen, 2006; Türkei-Beitritt, 2006). Zaczęła jednakże kłaść jeszcze większy nacisk na wdrażanie unijnych norm i standardów oraz protokołu z Ankary (Schiltz, 2006; Die EU steuert, 2006).

Pewnym wyrazem dezaprobaty dla postawy strony tureckiej, sceptycyzmu wobec akcesji i ukłonem w stronę oponentów rozszerzenia było niezaproszenie tureckiej delegacji przez niemiecką Prezydencję na obchody z okazji 50-lecia Unii. Nie wpłynęło to jednakże negatywnie na sam proces, gdyż otwarto rozmowy na temat rozdziału 20 - polityka przemysłowa i przedsiębiorczości. Przewodnicząca Radzie Europejskiej kanclerz zapowiadała otwarcie negocjacji w kolejnych obszarach do połowy 2007 r., ale pod warunkiem normalizacji stosunków z Cyprem (EU und Türkei, 2007; Osiewicz, 2009, s. 195). Wkrótce potem UE skupiła się na podpisaniu i ratyfikacji Traktatu reformującego UE, a kwestia akcesji Turcji oraz problemy wewnętrzne w tym kraju związane z wyborami parlamentarnymi i prezydenckimi zeszły na dalszy plan.

We wrześniu 2009 r. Marti Ahtisaari - były prezydent Finlandii - oraz kilku innych członków unijnej komisji ds. Turcji wezwali Unię do zintensyfikowania prac oraz praktycznego odblokowania procesu negocjacyjnego z Turcją (Leaders, 2009). Strona turecka potwierdzała, że członkostwo w UE nadal jest priorytetem (Osiewicz, 2009, s. 199). W połowie następnego roku otwarty został rozdział 12 - bezpieczeństwo żywności, polityka weterynaryjna i fitosanitarna. Odnośnie dalszych negocjacji z Unią 
Europejską Merkel jasno dawała do zrozumienia, że kolejne rozdziały negocjacyjne powinny zostać otwarte, ale gdy zostaną stworzone ku temu możliwości i warunki po obu stronach. Jednocześnie chwaliła Turcję za bardzo dobry wzrost gospodarczy, szczególnie w obliczu kryzysu, z którym borykały się niektóre państwa Eurogrupy. Premier Turcji Recep Tayyip Erdoğan skrytykował jednakże, jego zdaniem, zbyt małą pomoc Niemiec w tureckich staraniach o członkostwo (Pressestatements von Bundeskanzlerin Angela Merkel, 2011; Schlötzer, 2010).

Następnie, w maju 2012 r., uruchomiona została „Pozytywna Agenda”, która miała na celu nadanie dynamiki stosunkom turecko-unijnym (Osiewicz, 2015, s. 202; Fule, 2012). Podczas wizyty w Berlinie premiera Erdoğana Merkel zapewniała, iż rozmowy na temat przystąpienia Turcji do Unii posuwają się naprzód, nawet jeśli należy wyjaśnić kwestie o charakterze fundamentalnym. Niemcy popierają ten proces i mają szczególny interes w pogłębieniu wzajemnych relacji i powiązań między Turcją a UE. Kanclerz odniosła się również do tego, iż partia CDU wolałaby raczej uprzywilejowane partnerstwo niż członkostwo Turcji w UE słowami, iż „to jest kwestia, w której się nie zgadzamy. Ale nauczyliśmy się z tym żyć i nadal budować dobre relacje" (Pressestatements von Bundeskanzlerin Angela Merkel, 2011; Merkel sichert, 2013).

Wkrótce dzięki poparciu kanclerz otwarty został rozdział 22 - polityka regionalna i koordynacja elementów strukturalnych (Accession, 2013). Merkel nie widziała przeszkód, by również rozdziały dotyczące praworządności, sprawiedliwości i praw człowieka (23 i 24) zostały ,jak najszybciej otwarte” (Pressestatements der Bundeskanzlerin, 2014). Według kanclerz odnośnie otwartych negocjacji w sprawie przystąpienia Turcji do Unii Europejskiej wciąż obowiązywała ją zasada pacta sunt servanda (Merkel: Gemeinsames, 2014). Proponowała zatem dwustronne rozmowy z tureckim rząqem o szczegółach. Na temat udziału Turcji w posiedzeniach rad UE oświadczyła, iż należy „,znaleźć uporządkowany proces, jak ponownie włączyć państwa kandydujące w te prace" (Bundeskanzlerin, 2015; Pressekonferenz von Bundeskanzlerin Merkel und dem türkischen Ministerpräsidenten Davutoğlu, 2015; Pressestatements von Bundeskanzlerin Merkel und dem türkischen Präsidenten Erdoğan, 2015).

W listopadzie 2015 r. odbył się szczyt Turcja-UE, który posunął naprzód proces akcesyjny. Niedługo potem na posiedzeniu konferencji akcesyjnej otwarto negocjacje dotyczące rozdziału 17 - polityka gospodarcza i pieniężna. UE potwierdziła wage, jaką przywiązuje się do bliskich stosunków z Turcją. Przypomniała również, że państwo to może przyspieszyć tempo negocjacji (w ciagu 10 lat negocjacji otworzonych zostało 15 z 35 rozdziałów, z czego 1 tymczasowo zamknięto) przez postęp w realizacji wskaźników, poprzez spełnienie wymagań z ram negocjacyjnych oraz respektowanie umownych zobowiązań wobec Unii (Turcja, 2015).

\section{Demokratyzacja Turcji}

Jednym z najczęściej wysuwanych argumentów przeciwko przyjęciu Turcji do Unii jest niestabilna i niedojrzała demokracja oraz silny nacjonalizm turecki. Kwestie związane z demokratyzacją państwa tureckiego były najczęściej przywoływane przez kanclerz w kontekście wypełnienia kryteriów kopenhaskich, czyli istnienia instytucji 
gwarantujących stabilną demokrację, rządów prawa oraz szanowania praw człowieka i mniejszości (Schlötzer, 2010).

Od początku 2006 r. państwo to wprowadziło liczne zmiany do prawa krajowego, których celem była demokratyzacja ustroju republiki. Rząd turecki był przekonany, że UE zauważy i doceni jego wysiłki, zatem wyniki szczytu luksemburskiego przyjął z ogromnym rozczarowaniem. W konsekwencji tempo reform uległo spowolnieniu, co z kolei wywołało zarzuty ze strony Parlamentu Europejskiego. Europarlamentarzyści zarzucali stronie tureckiej opieszałość w procesie reform, zwłaszcza w zakresie wolności słowa (kodeks karny pozwalał na uwięzienie z powodu wyrażanych poglądów), praw religijnych (atakowano kościoły chrześcijańskie w Turcji) i praw mniejszości (nieuregulowana kwestia Ormian i Kurdów). Ostrzegano, że brak pełnego wykonania tych zobowiązań do końca 2006 r. negatywnie wpłynie na dalsze negocjacje (Koszel, 2008, s. 139-140). Chcąc zapoznać się dokładnie z sytuacją A. Merkel udała się z wizytą do Stambułu i Ankary (EU-Beitrittsverhandlungen, 2006). Podczas niej kanclerz podkreślała, iż „obecnie również Turcja bardzo wyraźnie dostrzega, że [kontynuowanie reform - przyp. A. B.] nie jest przysługą dla Europy, ale jest to również krok naprzód, wygrana Turcji. Bez reform, które zostały wdrożone, jej wzrost wcale nie byłby możliwy. Tak więc jest to sytuacja korzystna dla nas i dla niej [...]. Myślę, iż wszyscy są tego w pełni świadomi” (Türkei-Reise, 2006).

Prezentując w Bundestagu punkty ciężkości zbliżającej się niemieckiej prezydencji w Unii A. Merkel podkreślała, że tureckie członkostwo powiązane jest ze ścisłym wypełnianiem przyjętych przez to państwo zobowiązań i reform, w tym głębokich reform wewnętrznych dotyczących m.in. praw człowieka oraz wolności obywateli. Starając się uspokoić przeciwników akcesji mówiła, że unijni przywódcy ustalili bardziej rygorystyczne kryteria oraz powiązanie między rozszerzeniem Unii a możliwościami absorpcji przez nią nowych członków (Regierungserklärung von Bundeskanzlerin Dr. Angela Merkel zum, 2006; Europäische Union, 2006). W związku z niewielkimi postępami Turcji, w szczególności w zakresie reform politycznych, w lutym 2008 r. wprowadzono zmiany w unijnym programie Partnerstwo dla Członkostwa. Rada określiła krótko i średnioterminowe priorytety procesu akcesyjnego Turcji. Wśród tych, które miały zostać zrealizowane w ciagu jednego do dwóch lat, znalazły się: demokracja i państwo prawa, prawa człowieka i ochrona mniejszości oraz kwestie regionalne i zobowiązania międzynarodowe (Decyzja Rady, 2008).

Kryzys na tureckiej scenie politycznej związany z publiczną debatą nad zdelegalizowaniem rządzącej Partii Sprawiedliwości i Rozwoju - AKP - oraz wykluczeniem z życia publicznego premiera Erdoğana i prezydenta Abdullaha Güla zaniepokoił Unię oraz znalazł odzwierciedlenie w raporcie KE z 2008 r. Komisja podkreślała, iż zamiast wprowadzać niezbędne zmiany w konstytucji służące dostosowaniu do międzynarodowych standardów w zakresie praw podstawowych parlament turecki próbował znieść zakaz noszenia chust na państwowych uniwersytetach. Ponadto zwróciła uwagę na brak spójnego i kompleksowego rządowego programu reform politycznych oraz problemy w funkcjonowaniu głównych instytucji m.in. ze względu na brak porozumienia między istniejącymi głównymi siłami politycznymi. KE zalecała m.in. decentralizację władzy na rzecz samorządów oraz wprowadzenie zmian w wymiarze sprawiedliwości - np. ustanowienie regionalnych sądów apelacyjnych, wzmocnienie wysiłków w celu 
zapewnienia interpretacji przez sądy przepisów dotyczących praw człowieka i podstawowych wolności zgodnej z Europejską Konwencją Praw Człowieka (EKPC) oraz z orzecznictwem Europejskiego Trybunału Praw Człowieka. Zarzuciła Turcji brak osiagnięć w zakresie ratyfikacji instrumentów ochrony praw człowieka - nieratyfikowanie Protokołu fakultatywnego do Konwencji ONZ w sprawie zakazu stosowania tortur (OPCAT) oraz trzech dodatkowych protokołów do EKPC (Turkey 2008, 2008, s. 6-11).

Znamienny dla Turcji był 2009 r., w którym nastąpiła widoczna zmiana w polityce jej rządu odnośnie mniejszości narodowych - Kurdów i Ormian. Zakończono prace nad uruchomieniem kurdyjskiej telewizji oraz uruchomiono ormiańską stację radiową. Ponadto Rada Edukacji Wyższej (YÖK) zatwierdziła podanie Uniwersytetu Artuklu w Mardin o otwarcie Instytutu Żywych Języków, który miał prowadzić kształcenie podyplomowe w języku kurdyjskim oraz innych używanych w Turcji. W kilku prowincjach zaczęto oferować usługi publiczne w języku kurdyjskim. Złamane zatem zostało pewnego rodzaju tabu i podjęty dialog, który kilka lat wcześniej wydawał się niemożliwy. Prezydent A. Gül wykazał się światopoglądową liberalnością - jego podróż do Iraku, pierwsza podróż tureckiego prezydenta po 33 latach przerwy, przyczyniła się do zbudowania pozytywnej atmosfery wokół kwestii kurdyjskiej (Turkey 2009, 2009, s. 28). Mimo, iż pewne ograniczenia pozostały, dzięki tym zmianom kanclerz Merkel mogła mówić o zintensyfikowaniu prac oraz odblokowaniu procesu negocjacyjnego z Turcją (Deutschland/Türkei, 2010; Pressestatements von Bundeskanzlerin Merkel und dem türkischen Ministerpräsidenten Erdoğan, 2010).

Kolejne kroki w tym kierunku podjęte zostały w 2014 r. W czerwcu parlament turecki przyjął ustawę w celu znalezienia rozwiązania kwestii kurdyjskiej. Ustawa została przyjęta przy szerokim wsparciu wszystkich partii politycznych. Obejmowała ona działania wspomagające wyeliminowanie terroryzmu, wzmocnienie integracji społecznej oraz reintegracji tych, którzy opuszczą Partię Pracujących Kurdystanu (PKK) i złożą broń oraz przygotowujące opinię publiczną do powrotu byłych bojowników. Ustawa miała nie tylko wzmocnić podstawy ugody, ale również pozytywnie oddziaływać na stabilność i ochronę praw człowieka w Turcji (Turkey Progress, 2014, s. 3). A. Merkel wyrażała zadowolenie z postępów (ostatecznie przyjęto przepisy w obszarze rządów prawa, wolności wypowiedzi i wolności zgromadzeń, które niezgodne były ze standardami europejskimi) (Turkey 2015, 2015, s. 4). Wspominała także o wdrożeniu nowego pakietu sądowego (zmieniona strategia reformy sądownictwa została przyjęta w kwietniu 2015 r.). Nowo wybrany premier Ahmet Davutoğlu koncyliacyjnie zaproponował by w sprawach, które były przedmiotem debaty, udostępniano materiały, pokazujące czy zostały zasądzone uzasadnione kary (Pressekonferenz von Bundeskanzlerin Merkel und dem türkischen Ministerpräsidenten Prof, 2015).

W grudniu 2015 r. Unia potwierdziła swoją gotowość do wspierania Turcji w działaniach reformatorskich, podkreślając potrzebę szybkich zmian w zakresie praworządności i podstawowych praw. Silnie poparła starania o pokojowe rozwiązanie kwestii kurdyjskiej (władze tureckie rozpoczęły szeroką antyterrorystyczną kampanię przeciwko PKK w związku z atakiem na pokojową demonstrancję w Ankarze, który miał miejsce 10 października) i zachęciła wszystkie strony do dalszego zaangażowania, tak by proces ten mógł się toczyć (Turcja, 2015). 


\section{Stosunki z Cyprem i konflikt cypryjski}

Nierozwiązany konflikt cypryjski jest jednym z częściej poruszanych przez kanclerz argumentów związanych $\mathrm{z}$ akcesją Turcji do UE. Niedługo po objęciu urzędu kanclerskiego A. Merkel wezwała władze tureckie do otworzenia portów i lotnisk dla statków oraz samolotów z Republiki Cypru, czyli respektowania protokołu dodatkowego do układu stowarzyszeniowego (EU-Beitrittsverhandlungen, 2006; Türkei-Reise, 2006; Koszel, 2008, s. 140). Powtarzała, iż również Turcję obowiązuje zasada pacta sunt servanda i musi „wypełnić swoje obowiązki, w przeciwnym razie Unia Europejska wyciagnie odpowiednie konsekwencje" (Rede von Bundeskanzlerin Dr. Angela Merkel im, 2006). Identyczne stanowisko zajął Parlament Europejski, który powiązał uregulowanie stosunków z Cyprem z dalszymi negocjacjami w kwestii członkostwa. Naciskany przez nią premier R. T. Erdoğan, próbował połączyć takie działanie ze zniesieniem przez Unię ograniczeń handlowych w Północnym Cyprze (EU-Beitrittsverhandlungen, 2006; Koszel, 2008, s. 139-140). Brak porozumienia spowodował, iż wygłaszając oświadczenie rządu oraz podczas spotkania Trójkąta Weimarskiego kanclerz mówiła o konieczności częściowego zawieszenia negocjacji z Ankarą (Regierungserklärung von Bundeskanzlerin Dr. Angela Merkel zum, 2006; Türkei-Beitritt, 2006). Ponieważ Turcja odmawiała uznania, iż protokół z Ankary odnosi się również do greckiej części Cypru, Rada na grudniowym szczycie zdecydowała o zamrożeniu 8 rozdziałów negocjacyjnych oraz wykluczyła zamknięcie jakiegokolwiek z uwagi na niewywiązywanie się Turcji ze zobowiązań gospodarczych, będących warunkiem unii celnej (Brussels, 2007).

Rząd turecki mówił, co prawda, o swym zaangażowaniu w kompleksowe rozwiązanie problemu cypryjskiego pod auspicjami Organizacji Narodów Zjednoczonych oraz przyjął z zadowoleniem rozpoczęcie negocjacji między przywódcami obu społeczności cypryjskich (Kwestia, 2011, s. 24-25)1, ale nie podjął żadnych konkretnych kroków (Turkey 2008, 2008, s. 28). W związku z powyższym podczas kwietniowej wizyty premiera Erdoğana w Berlinie kanclerz A. Merkel wyraziła nadzieję na postęp w rokowaniach UE z Turcją warunkując go normalizacją stosunków z Cyprem (Merkel and Erdogan, 2007).

Również w 2008 i 2009 r. Turcja nie poczyniła żadnych postępów w kierunku pełnego wdrożenia protokołu z 1970 r. i nie otworzyła portów zamkniętych dla statków z Republiki Cypryjskiej, pomimo kilku wezwań ze strony UE. W grudniowych konkluzjach Rady ds. Ogólnych i Stosunków Zewnętrznych spełnienie przez Turcję obowiązku pełnego wdrożenia owego protokołu uznano za kwestię pilną. Ponadto Rada oczekiwała od Turcji aktywnego wspierania toczących się negocjacji oraz podjęcia praktycznych kroków, które przyczynią się do stworzenia klimatu sprzyjającego

18 lipca 2006 r. podsekretarz generalny ONZ do spraw polityki, Ibrahim Gambari przedstawił „Zbiór zasad” uzgodniony przez prezydenta Republiki Cypru Tassosa Papadopoulosa i przywódce Turków cypryjskich, Mehmeta Aliego Talata. Porozumienie m.in. zobowiązało obie strony do zjednoczenia Cypru na zasadach dwustrefowej, dwuspołecznościowej federacji i politycznej równości, zgodnie z odnośnymi rezolucjami Rady Bezpieczeństwa ONZ. Niecały rok później Talat wniósł o zmianę uzgodnionych ram porozumienia. Pierwsze prace nad realizacją porozumienia rozpoczęły się w kwietniu $2008 \mathrm{r}$. 
sprawiedliwemu, wszechstronnemu i trwałemu rozwiązaniu problemu Cypru, zgodnie z odpowiednimi rezolucjami Rady Bezpieczeństwa ONZ oraz z zasadami, na których opiera się Unia (Konkluzje Rady, 2008, s. 5; Turkey 2009, 2009, s. 32). Według kanclerz z faktu, iż w konflikt zaangażowany jest Cypr będący członkiem Unii Europejskiej oraz Turcja będąca członkiem Paktu Północnoatlantyckiego wyniknęło wiele komplikacji we współpracy w ramach Europejskiej Polityki Bezpieczeństwa i Obrony oraz NATO. „Architektura zabezpieczeń” opiera się bowiem na sprawności NATO i Unii Europejskiej (Rede von Bundeskanzlerin Dr. Angela Merkel auf der 41, 2008). Merkel przekonywała, że dzięki dobrej woli wszystkich stron ten konflikt musi i może być rozwiązany. Obiecała, iż Niemcy będą również się do tego przyczyniać (Rede von Bundeskanzlerin Dr. Angela Merkel auf der Deutschen, 2008).

Jako że Turcja nie poczyniła postępów w kierunku normalizacji stosunków dwustronnych z Republiką Cypru i wciąż wetowała członkostwo tego państwa w wielu organizacjach międzynarodowych podczas wizyty w Ankarze pod koniec marca $2010 \mathrm{r}$. kanclerz Merkel obiecywała, iż zrobi wszystko co w jej mocy, żeby polepszyć owe stosunki (Rede der Bundeskanzlerin beim Deutsch-Türkischen, 2010). Po raz kolejny podkreślała, iż rząd federalny opowiada się za kontynuowaniem rozmów na temat członkostwa Turcji w Unii, ale pod warunkiem rozwiązania istniejącego konfliktu (Deutschland/Türkei, 2010).

Podczas spotkania z prezydentem Republiki Cypryjskiej - Demetrisem Christofiasem - kanclerz chwaliła gotowość do kompromisu i podejmowane wysiłki celem wznowienia bezpośrednich rozmów ze stroną turecką. Starania te nie zostały jednakże docenione przez Turcję, która w drugiej połowie 2012 r. ogłosiła bojkot prezydencji Cypru w Radzie UE i straszyła, iż zawiesi negocjacje akcesyjne w tym czasie (ostatecznie do tego nie doszło). Działania te obliczone były na wywarcie na tyle silnej presji na Unię, aby odblokowała znajdujący się w impasie proces negocjacji akcesyjnych oraz zniosła obowiązek wizowy dla obywateli tureckich, wjeżdżających na teren UE (Ananicz, 2012). Nie przyniosły one jednak zamierzonego efektu.

Poproszona przez premiera Erdoğana o pomoc w odblokowaniu rozmów z Unią w lutym 2013 r. Merkel zripostowała, że niezbędne do tego są postępy w realizacji protokołu dodatkowego, gdyż w przeciwnym razie liczba otwartych rozdziałów będzie mała i ograniczona. Jednocześnie podkreślała, że rezultat jej mediacji, zależy od działania stron bezpośrednio zaangażowanych w konflikt (Bürger, 2013). Erdoğan sugerował, iż strona turecka podjęła sporo kroków, ale ,nie dostała nic w zamian” (Pressekonferenz von Bundeskanzlerin Merkel und dem türkischen Ministerpräsidenten Erdoğan, 2013). W tym czasie w impasie znajdowały się również rozmowy greckich i tureckich Cypryjczyków (zostały one zupełnie zawieszone przez stronę turecką na czas cypryjskiej Prezydencji). Stronom nie udało się osiagnąć takiego postępu w rokowaniach, który pozwoliłby na porozumienie we wszystkich kwestiach (Osiewicz, 2012, s. 183-184).

Pod koniec 2014 r. Komisja Europejska wezwała wszystkie państwa kandydujące, a zatem również Turcję, choć niewymienioną z nazwy, do jak najszybszego uregulowania wszelkich spornych kwestii w ramach stosunków dwustronnych zarówno z innymi kandydatami, jak i państwami członkowskimi UE (Strategia, 2014, s. 1). Następnie podczas majowego posiedzenia Rady Stowarzyszenia UE-Turcja wyrażo- 
no nadzieję, że Turcja będzie aktywnie wspierać negocjacje mające doprowadzić do sprawiedliwego, kompleksowego i trwałego rozwiązania kwestii cypryjskiej, zgodnie z odpowiednimi rezolucjami Rady Bezpieczeństwa ONZ i z zasadami, na których opiera się Unia. Przedstawiciele Unii podkreślali, że zapewnienie pozytywnej atmosfery w celu wznowienia negocjacji cypryjskich jest ważniejsze niż kiedykolwiek (Rada, 2015). Dobrym krokiem w tym kierunku było poparcie przez stronę turecką powrotu do rozmów przywódców cypryjskich Turków i cypryjskich Greków (Turkey 2015, 2015, s. 5).

Jako iż trudno wyobrazić sobie sytuację, w której Turcja mogłaby stać się członkiem UE, nie uznając jednego z państw członkowskich podczas konferencji prasowej z okazji grudniowego szczytu Unia-Turcja Merkel podkreślała, iż „oczywiste jest, że przebieg procesu akcesyjnego Turcji i otwarcie rozdziałów są bardzo ściśle związane z postępami w kwestii Cypru" i wyraziła nadzieję, że w następnych miesiącach uda się ten konflikt rozwiązać (Pressekonferenz von Bundeskanzlerin Merkel beim EU, 2015).

\section{Imigranci tureccy w Niemczech}

Jedną z bardziej problematycznych kwestii podnoszonych przez kanclerz w związku z akcesją Turcji jest możliwość napływu do Niemiec taniej siły roboczej. Według Merkel dzięki temu nastąiłoby „odmłodzenie” społeczności niemieckiej, co miałoby pozytywne znaczenie dla systemów ubezpieczeń społecznych i emerytalnych starzejącego się społeczeństwa. W związku z wyrażaną przez Niemców dezaprobatą oraz licznymi sporami między rządem tureckim i niemieckim dotyczącymi mniejszości tureckiej w RFN kanclerz stosunkowo rzadko wypowiada się na ten temat. Integracja tej mniejszości, jak i innych mniejszości zamieszkujących RFN, jest jednak dla niej niezwykle ważna. Świadczy o tym chociażby to, iż z jej inicjatywy od 2006 r. zaczęto organizować szczyty integracyjne, na których organizacje migracyjne dyskutują o problemach środowisk mniejszościowych. Jednym z efektów tych szczytów jest Narodowy Plan Integracji z 2007 r. (Der Nationale, 2007).

A. Merkel świadoma jest, iż napływ w latach 50-tych i 60-tych tzw. gastarbeiterów z południowej Europy i Turcji w znacznym stopniu przyczynił się do tzw. cudu gospodarczego Niemiec. Jednocześnie zauważa, iż „integracja mieszkających u nas współobywateli ze środowisk imigracyjnych jest ważnym, kompleksowym zadaniem. [...] Mamy oczywiście, jeśli chcemy integrować i dać ludziom dom, szczególne zadanie zapewnienia wszystkim równych szans: w kształceniu, wejściu w życie zawodowe, udziale w dobrobycie" (Rede von Bundeskanzlerin Dr. Angela Merkel beim, 2006).

Szczególnie kwestia wykształcenia jest wielokrotnie podnoszona przez Merkel, zarówno w kontekście edukowania imigrantów tureckich w RFN, jak i napływu dobrze wykształconych Turków. Od momentu objęcia urzędu kanclerskiego podkreśla jak ważna jest dobra znajomość języka niemieckiego, która umożliwia rozwój i zdobycie pracy. Przekonywała, iż ze względu na starzejące się niemieckie społeczeństwo „potrzebujemy każdego z dobrym wykształceniem. Nie możemy być odpowiedzialni, jeśli spojrzymy na to chociażby od strony ekonomicznej, [...] za brak pomocy w zdo- 
byciu wykształcenia i przez to za skazanie imigrantów na bezrobocie" (Türkei-Reise, 2006). Niejednokrotnie wyrażała ubolewanie, iż ,procent młodych ludzi tureckiego pochodzenia, którzy nie ukończyli szkoły i nie posiadają wykształcenia zawodowego, jest nadal wyższy niż młodych ludzi pochodzenia niemieckiego". Będąc przekonaną, iż Turcy są tak samo inteligentni jak Niemcy konstatowała, iż ,taka sama ich liczba musi kończyć naukę i zdobyć dyplom, iść do szkoły zawodowej lub na uniwersytet”. Kanclerz zwracała również uwagę na różnice w podejściu do kształcenia dziewczynek i chłopców. Podjęła się zadania by szczerze przedyskutować ze stroną turecką „niepokojące” kwestie dotyczące równouprawnienia kobiet, m.in. „czy dziewczynki są tak samo kształcone jak chłopcy, czy mają takie same możliwości oraz w jakich zajęciach moga uczestniczyć w niemieckiej szkole" (Rede von Bundeskanzlerin Dr. Angela Merkel zum, 2006; Rede von Bundeskanzlerin Dr. Angela Merkel beim, 2007). Prowadziła również ze stroną turecką rozmowy dotyczące tego, czy ,,partnerzy, którzy podróżują do Niemiec poślubić Niemca/Niemkę tureckiego pochodzenia powinni rozpoczynać kursy językowe już w ojczyźnie. To po prostu musi być jasne, że oba państwa chca, by ludzie mogli wysławiać się poprawnie w języku [kraju do którego przybywaja]" (Türkei-Reise, 2006). Ta swego rodzaju „oczywista oczywistość” wywołała w Turcji, z jednej strony, ostre głosy krytyki mówiące o niemieckiej polityce asymilacyjnej wobec obcokrajowców, z drugiej, apele o integrację tureckich imigrantów z niemieckim społeczeństwem (Türkischer Staatspräsident, 2010).

Merkel nieprzychylna jest również pomysłowi powstania dwujęzycznych szkół w Niemczech. Wysuwane przez Erdoğana żądania utworzenia w RFN tureckich gimnazjów potraktowała jako nieuzasadnione i sprzeczne z niemiecką polityką wobec imigrantów. Ponadto konsekwentnie odrzuca apele tureckiego premiera o zaakceptowanie możliwości jednoczesnego posiadania tureckiego i niemieckiego obywatelstwa przez imigrantów (Wieliński, 2010; Turecki, 2010).

\section{Syria i uchodźcy syryjscy}

Kanclerz wielokrotnie podkreślała, iż powstrzymanie napływu syryjskich uchodźców uwarunkowane jest bardzo bliską współpracą i udzieleniem Turcji wsparcia w zakresie pomocy humanitarnej, w obszarze zabezpieczenia granic i zwalczania grup przestępczych (Pressekonferenz von Bundeskanzlerin Merkel zum informellen, 2015; Rede von Bundeskanzlerin Merkel zum, 2015). Choć A. Merkel zaprzecza, że współpraca z Turcją odnośnie wojny w Syrii i migracji obywateli tego państwa jest powiązana z politycznymi aspektami, jak stowarzyszenie czy przystąpienie do Unii, nie można nie dostrzec istniejących powiązań.

W grudniu 2013 r. Unia Europejska i Turcja podpisały umowę o readmisji. Ankara zobowiązała się nią do przyjmowania nielegalnych imigrantów (zarówno Turków, jak i obywateli państw trzecich lub bezpaństwowców), którzy dostali się na teren Unii z Turcji. W stosunku do obywateli Turcji umowa miała zacząć obowiązywać po ratyfikacji przez parlament, zaś w odniesieniu do obywateli państw trzecich i bezpaństwowców - 3 lata po ratyfikacji (Umowa, 2014; Ananicz, 2013). Równolegle Turcja i UE rozpoczęły rozmowy o ,planie działania” na rzecz ruchu bezwizowego z Turcją, 
czyli programie 72 reform dotyczących m.in. tureckiej polityki zarządzania granicami i migracją. Spełnienie wymogów było warunkiem, ale nie gwarancją, stawianym przez Unię dla krótkoterminowego (do 90 dni) zniesienia wiz dla obywateli Turcji. Ankara miała nadzieję, że nastąpi to w październiku 2016 r. (Roadmap, 2013; Szczyt przywódców, 2015).

Po przyznaniu Turcji przez Komisję Europejską statusu bezpiecznego kraju pochodzenia A. Merkel zaproponowała premierowi Erdoğanowi ,przyspieszony proces wizowy" w zamian za szybsze wprowadzenie przez Turcję umowy o readmisji (Bundeskanzlerin Merkel in der Türkei, 2015; Pressekonferenz von Bundeskanzlerin Merkel und dem türkischen Ministerpräsidenten Davutoğlu, 2015; Pressestatements von Bundeskanzlerin Merkel und dem türkischen Präsidenten Erdoğan, 2015). Podczas listopadowej konferencji prasowej zorganizowanej z okazji nieformalnego szczytu w Valletcie w 2015 r., kanclerz podkreślała, iż „,chodzi o dwa procesy, z jednej strony o liberalizację reżimu wizowego dla Turcji, który już się odbywa. Proces ten powinien być przyspieszony. W zamian, Turcja jest gotowa wprowadzić w życie wcześniej umowę o readmisji dla obywateli państw trzecich. Te dwa procesy negocjacji są ze sobą połączone. Oczywiście jeśli chodzi o liberalizację reżimu wizowego nie będą uchylane żadne standardy, które mają zastosowanie do innych krajów, ale proces ten można przyspieszyć" (Pressekonferenz von Bundeskanzlerin Merkel beim informellen, 2015). W trakcie odbywającego się dwa tygodnie później szczytu przywódców państw członkowskich i Turcji uzgodniono, iż do czerwca 2016 r. strona turecka będzie gotowa przyjąć z powrotem obywateli państw trzecich w ramach umowy o readmisji, i w rezultacie w drugiej połowie roku, podjęta zostanie decyzja, czy spełnia warunki dla ruchu bezwizowego. Dzięki temu, według Merkel, stworzona została podstawa dhugoterminowego partnerstwa z Turcją w zakresie polityki migracyjnej (Regierungserklärung von Bundeskanzlerin Merkel, 2015).

Kanclerz zwracała również dużą uwagę na polepszenie sytuacji uchodźców w obozach w Turcji. Stała bowiem na stanowisku, iż powstrzyma to część z nich przed migracją do państw Unii Europejskiej. Ponadto przekonywała, iż pozostanie blisko granicy syryjskiej będzie sprzyjać powrotowi uchodźców do Syrii (po uspokojeniu się sytuacji w ojczyźnie). Co do pozostałych uchodźców, którzy będą próbowali emigrować do państw unijnych, postulowała utworzenie „Hotspotów”, czyli miejsc na zewnętrznych granicach UE, w których uciekający dowiedzą się, czy otrzymają azyl. Tę formę kontroli i legalizację przepływu uchodźców wspomagać miało utworzenie niemiecko-tureckiej grupy roboczej (Rede von Bundeskanzlerin Merkel zum, 2015). Podczas wizyty w Stambule pod koniec października 2015 r. kanclerz pozytywnie odniosła się do zapewnień strony tureckiej odnośnie poprawy położenia uchodźców np. w kwestii świadczeń socjalnych i zdrowotnych. W zamian UE przejęła na siebie część tureckich obciążeń finansowych, odnosząc się z uznaniem do znacznego wysiłku Turcji, która przyjęła ok. 2 mln uchodźców uciekających przed przemocą z Syrii i Iraku (Bundeskanzlerin Merkel, 2015; Pressekonferenz von Bundeskanzlerin Merkel und dem türkischen Ministerpräsidenten Davutoğlu, 2015; Pressestatements von Bundeskanzlerin Merkel und dem türkischen Präsidenten Erdoğan, 2015).

Kanclerz postulowała również zintensyfikowanie dialogu obu państw dotyczącego zwalczania terroryzmu. Mówiła o tym, jak ważne jest, ,abyśmy zrobili wszystko co 
możliwe w Niemczech, by nie tylko zapobiec działaniom terrorystycznym, ale również by nasze kraje wymieniły się [informacjami] i przede wszystkim by dawały do zrozumienia, że Niemcy chcą pokojowego współistnienia muzułmanów i tych, którzy należą do innych religii" (Pressekonferenz von Bundeskanzlerin Merkel und dem türkischen Ministerpräsidenten Prof, 2015). Podczas majowego posiedzenia Rady Stowarzyszenia UE-Turcja podkreślono, iż należy ściślej współpracować przeciwko Państwu Islamskiemu i źródłom jego finansowania oraz powstrzymywać napływ zagranicznych bojowników. Z zadowoleniem wspomniano o czynnym unijno-tureckim dialogu w sprawie przeciwdziałania terroryzmowi oraz o wymianie sprawdzonych rozwiązań co do zapobiegania radykalizacji postaw i werbunkowi terrorystów (Rada Stowarzyszenia, 2015).

$$
* * *
$$

Po 10 latach od oficjalnego otwarcia negocjacji akcesyjnych Republika Turcji wciąż nie jest członkiem Unii Europejskiej. Złożyło się na to wiele przyczyn - te najczęściej wspominane przez kanclerz Angelę Merkel, to niestabilna demokracja i brak poszanowania jej zasad, nierozwiązany konflikt cypryjski, łamanie praw człowieka (w tym kobiet) i prześladowanie mniejszości narodowych.

Turcja ze swej strony stara się dostosować swoje prawo do obowiązujących unijnych przepisów, jednakże wiele ważnych reform jeszcze nie wprowadzono w życie albo wręcz przyjęto przepisy niezgodne z unijnymi standardami w dziedzinie państwa prawa, wolności wypowiedzi i wolności zgromadzeń. Choć większość istniejących partii ma swoją reprezentację w parlamencie, na scenie politycznej wciąż istnieją głębokie podziały. Świadczy o tym chociażby fakt, iż w związku z przekroczeniem konstytucyjnego terminu dla utworzenia rządu po wyborach w czerwcu 2015 r., musiały zostać one powtórzone (1 listopada). Nie można przy tym nie wspomnieć, iż kampania wyborcza toczyła się w okresie wewnętrznego kryzysu państwa powiązanego z odnowieniem się konfliktu z Kurdami, zamachami terrorystycznymi i atakami na opozycyjne wobec władz media. Nie widać również dostatecznej chęci do zreformowania administracji. Kwestionować można także niezależność wymiaru sprawiedliwości w związku z wywieraną na prokuratorów i sędziów presją polityczną. Niepokojące jest również wytaczanie spraw o przestępstwa kryminalne dziennikarzom, pisarzom, użytkownikom mediów społecznościowych oraz zmiana regulacji dotyczących internetu (zwiększenie uprawnień rządu do blokowania treści bez nakazu sądowego) (Turkey 2015, 2015, s. 5).

Turcja poparła, co prawda, wznowienie rozmów przywódców cypryjskich Greków i cypryjskich Turków, ale wciąż nie usunęła wszystkich przeszkód dla swobodnego przepływu towarów, w tym ograniczeń dla bezpośrednich połączeń transportowych z Republiką Cypryjską. Nie było też żadnych postępów w normalizacji stosunków dwustronnych z tym państwem. Dopóki Turcja nie wdroży w pełni protokołu dodatkowego do układu o stowarzyszeniu nie będą mogły zostać otwarte negocjacje w ośmiu rozdziałach oraz żaden otwarty rozdział nie zostanie zamknięty. Turcja musi jednoznacznie zobowiązać się do stosunków dobrosąsiedzkich i pokojowego rozwiązywania 
sporów zgodnie z Kartą Narodów Zjednoczonych, odwołując się, jeśli to konieczne, do Międzynarodowego Trybunału Sprawiedliwości. W tym kontekście UE wyrażała po raz kolejny poważne obawy i wzywała Turcję do unikania działań skierowanych przeciwko państwu członkowskiemu, jakim jest Cypr, i do pokojowego rozwiązywania sporów (Turkey 2015, 2015, s. 6).

Stanowczość Unii Europejskiej wystawiona jest jednakże na poważną próbę m.in. ze względu na toczącą się wojnę w Syrii i potężny napływ uchodźców z tego państwa na terytorium UE. W związku ze współpracą Turcji w zahamowaniu owego przepływu państwu temu udało się wynegocjować przyspieszenie liberalizacji procesu wizowego dla swych obywateli oraz posunąc naprzód negocjacje akcesyjne (otwarcie rozdziału 17). Jako że Unia potrzebuje Turcji by uporać się z tym kryzysem, na chwilę obecną prawdopodobne są dwa scenariusze. Pierwszy, mimo wielu zastrzeżeń UE uzna, iż współpraca i zaangażowanie Turcji równoważą jej niedociagnięcia w wypełnianiu kryteriów akcesyjnych i będą otwierane kolejne rozdziały z zamiarem faktycznej akcesji. Drugi, Unia nie chcąc stracić cennego sprzymierzeńca w walce z kryzysem uchodźczym będzie zacieśniać współpracę, otwierać kolejne rozdziały negocjacyjne, ale bez gwarancji akcesji, odsuwając jej datę w bardzo daleką przyszłość i wiążąc z wypełnieniem wszystkich kryteriów. Z wypowiedzi Angeli Merkel wynika, iż będzie raczej opowiadać się za wielopłaszczyznową współpraca, zacieśnianiem stosunków tego państwa z Unią, iż skłonna będzie do ewentualnych ustępstw wobec oczekiwań strony tureckiej, ale nie na tyle daleko idących, żeby zlekceważyć niespełnianie kryteriów i zaaprobować akcesję Turcji do UE.

\section{Bibliografia}

Abkommen zur Gründung einer Assoziation zwischen der Europäischen Wirtschaftsgemeinschaft und der Türkei, Amtsblatt der Europäischen Gemeinschaften, 29. Dezember 1964, 7. Jahrgang Nr. 217, G 1203 B, http://eur-lex.europa.eu/legal-content/DE/TXT/PDF/?uri= OJ:P:1964:217:FULL\&from=PL, 15.01.2016.

Accession Conference at Ministerial level opens negotiations with Turkey on Chapter 22 - Regional Policy and Coordination of Structural instruments, Brussels, 5 November 2013, 15694/13 (OR. en), PRESSE 451, 2013, http://data.consilium.europa.eu/doc/document/ST-156942013-INIT/en/pdf, 15.01.2016.

Additional Protocol signed at Brussels 23 November 1970, Official Journal of the European Communities, 24 December 1973, vol. 16, no. C 113, http://ec.europa.eu/enlargement/pdf/turkey/ association_agreement_1964_en.pdf, 15.01.2016.

Ananicz S. (2012), Prezydencja cypryjska a relacje Turcji z Uniq Europejska, 26.06.2012, http:// www.osw.waw.pl/pl/publikacje/komentarze-osw/2012-06-26/prezydencja-cypryjska-a-relacje-turcji-z-unia-europejska, 15.01.2016.

Ananicz S. (2013), Turcja i UE: Przełom w negocjacjach wizowych i o readmisji, 18.12.2013, http:// www.osw.waw.pl/pl/publikacje/analizy/2013-12-18/turcja-i-ue-przelom-w-negocjacjachwizowych-i-o-readmisji, 15.01.2016.

Archiv der Gegenwart, 1987.

Archiv der Gegenwart, 1997.

Brussels European Council 14/15 December 2006, Presidency Conclusions, Brussels, 12 February 2007, 16879/1/06, REV 1, CONCL 3, http://www.consilium.europa.eu/ueDocs/cms_Data/ docs/pressData/en/ec/92202.pdf, 15.01.2016. 
Bundeskanzlerin Merkel in der Türkei. Flüchtlingsthema gemeinsam angehen, 18.10.2015, http:// www.bundeskanzlerin.de/Content/DE/Reiseberichte/2015-10-18-tuerkei-montag.html, 15.01.2016.

Bürger als Brücke zwischen den Ländern, 25.02.2013, http:/www.bundeskanzlerin.de/ContentArchiv/DE/Archiv17/Reiseberichte/2013-02-25-merkel-tuerkei.html, 15.01.2016.

Decyzja Rady 2008/157/WE z dnia 18 lutego 2008 r. w sprawie zasad, priorytetów $i$ warunków zawartych $w$ partnerstwie dla czlonkostwa zawartym z Republika Turcji oraz uchylajaca decyzje 2006/35/WE, http://eur-lex.europa.eu/legal-content/PL/TXT/HTML/?uri=URISERV:e40111\&from=EN, 15.01.2016.

Der Nationale Integrationsplan, 2007, https://www.bundesregierung.de/Webs/Breg/DE/Bundesregierung/BeauftragtefuerIntegration/nap/nip/_node.html, 15.01.2016.

Deutschland/Türkei. Deutschland und die Türkei: Partner in Europa, 30.03.2010, http://www.bundeskanzlerin.de/ContentArchiv/DE/Archiv17/Artikel/2010/03/2010-03-29-ankara-erstertag-tuerkei.html, 15.01.2016.

EU und Türkei: die enge Zusammenarbeit weiter intensivieren, 15.04.2007, http://www.bundesregierung.de/Content/DE/Artikel/2007/04/2007-04-15-bk-erdogan-hannover.html, 15.01.2016.

EU-Beitrittsverhandlungen mit Türkei ergebnisoffen, 6.10.2006, http://www.bundeskanzlerin. de/ContentArchiv/DE/Archiv17/Reiseberichte/tr-eu-beitrittsverhandlungen-mit-tuerkeiergebnisoffen.html, 15.01.2016.

Europäische Union. Gute Voraussetzungen für deutsche EU-Präsidentschaft, 15.12.2006, http:// www.bundeskanzlerin.de/ContentArchiv/DE/Archiv17/Reiseberichte/be-2006-12-15bruessel.html, 15.01.2016.

Fule S. (2012), Turkey and EU: common challenges, common future, 10.11.2012, http://avrupa.info. tr/resource-centre/news-archive/news-single-view/article/turkey-and-the-eu-common-challenges-common-future.html, 15.01.2016.

Gemeinsam fûr Deutschland - mit Mut und Menschlichkeit. Koalitionsvertrag zwischen CDU, CSU und SPD, 11.11.2005, http://www.cdu.de/doc/pdf/05_11_11_Koalitionsvertrag.pdf, 15.01.2016.

Guttenberg K.-Th. (2004), Die Beziehungen zwischen der Tûrkei und der EU - eine „priviligierte Partnerschaft”, „Aktuelle Analysen”, nr 33, http://www.hss.de/fileadmin/migration/downloads/aa33_internet.pdf.

Konkluzje Prezydencji, 16238/1/04, REV 1, CONCL 4, 16-17 grudnia 2004 r., http://www.consilium. europa.eu/uedocs/cms_data/docs/pressdata/pl/ec/83216.pdf, 15.01.2016.

Konkluzje Rady w sprawie rozszerzenia, Bruksela, 8 grudnia 2008 r. (09.12), (OR. fr), 16981/08, ELARG 130, http://register.consilium.europa.eu/doc/srv?l=PL\&t=PDF\&gc=true \&sc=false$\& \mathrm{f}=\mathrm{ST} \% 2016981 \% 202008 \% 20 \mathrm{INIT}, 15.01 .2016$.

Koszel B. (2008), ,, Uprzywilejowane partnerstwo”. Rzqd Angeli Merkel (CDU/CSU-SPD) wobec integracji Turcji z Uniq Europejskq, ,Rocznik Integracji Europejskiej”, nr 2.

Kwestia cypryjska. Krótkie wprowadzenie (2011), http://www.mfa.gov.cy/mfa/Embassies/Embassy_Warsaw.nsf/All/2E894BC56322D0D2C1257AE7004086A9/\$file/Kwestia\%20cypryjska.\%20Kr\%C3\%B3tkie\%20wprowadzenie\%20(2011).pdf, 15.01.2016.

Leaders urged to unblock Turkey's EU bid, 8.09.2009, http://www.euractiv.com/en/enlargement/leaders-urged-unblock-turkey-eu-bid/article-185202\#, 15.01.2016.

Merkel sichert Türkei ehrliche Verhandlungen zu, 31.10.2013, http://www.bundeskanzlerin.de/ ContentArchiv/DE/Archiv17/Artikel/2012/10/2012-10-31-treffen-merkel-erdogan.html, 15.01.2016.

Merkel: Gemeinsames strategisches Interesse, 4.02.2014, http:/www.bundeskanzlerin.de/Content/ DE/Artikel/2014/02/2014-02-04-besuch-tuerk-mp-erdogan.html, 15.01.2016. 
Ondarza P. (2005), Türkei und christliches Abendland: was in der Debatte um einen Beitritt vergessen wird: die Gechichte des Christentums, „Internationale Politik”, nr 7.

Osiewicz P. (2015), 10 lat negocjacji akcesyjnych Turcji z Uniq Europejska. Analiza postępów w obszarze kryteriów politycznych na podstawie raportów Komisji Europejskiej, „Rocznik Integracji Europejskiej”, nr 9.

Osiewicz P. (2012), Kwestia cypryjska: przebieg i konsekwencje rokowań w latach 2008-2012, „Rocznik Integracji Europejskiej”, nr 6.

Osiewicz P. (2009), Turcja na drodze do członkostwa w UE: uwarunkowania, przebieg oraz perspektywy negocjacji akcesyjnych, ,Rocznik Integracji Europejskiej”, nr 3.

Plenarprotokoll 15/148, Deutscher Bundestag, Stenografischer Bericht 148. Sitzung, Berlin, Donnerstag, den 16. Dezember 2004, Tagesordnungspunkt 3, Dr. Angela Merkel (CDU/CSU).

Pressekonferenz von Bundeskanzlerin Merkel beim EU-Türkei-Gipfel am 29. November 2015 in Brüssel, 29.11.2015, http://www.bundesregierung.de/Content/DE/Mitschrift/Pressekonferenzen/2015/11/2015-11-30-merkel-bruessel.html, 15.01.2016.

Pressekonferenz von Bundeskanzlerin Merkel beim informellen Treffen der Staats- und Regierungschefs der EU am 12. November 2015 in Valletta, 12.11.2015, http://www.bundeskanzlerin.de/Content/DE/Mitschrift/Pressekonferenzen/2015/11/2015-11-12-merkel-valletta-eusonderrat.html, 15.01.2016.

Pressekonferenz von Bundeskanzlerin Merkel und dem türkischen Ministerpräsidenten Davutoğlu in Istanbul, 18.10.2015, http://www.bundeskanzlerin.de/Content/DE/Mitschrift/Pressekonferenzen/2015/10/2015-10-19-merkel-davuto\%C4\%9Flu.html, 15.01.2016.

Pressekonferenz von Bundeskanzlerin Merkel und dem türkischen Ministerpräsidenten Prof. Davutoğlu am 12.01.2015 im Bundeskanzleramt, 12.01.2015, http://www.bundeskanzlerin. de/Content/DE/Mitschrift/Pressekonferenzen/2015/01/2015-01-12-merkel-davutoglu.html, 15.01.2016.

Pressekonferenz von Bundeskanzlerin Merkel und dem türkischen Ministerpräsidenten Erdoğan in Ankara, 25.02.2013, http://www.bundeskanzlerin.de/ContentArchiv/DE/Archiv17/Mitschrift/Pressekonferenzen/2013/02/2013-02-25-merkel-erdogan.html, 15.01.2016.

Pressekonferenz von Bundeskanzlerin Merkel zum informellen Treffen der Staats- und Regierungschefs der Europäischen Union in Brüssel, 24.09.2015, http:/www.bundeskanzlerin.de/ Content/DE/Mitschrift/Pressekonferenzen/2015/09/2015-09-24-merkel-sonder-er.html, 15.01.2016.

Pressestatements der Bundeskanzlerin und des türkischen Ministerpräsidenten am 4. Februar 2014 in Berlin, 4.02.2014, http://www.bundeskanzlerin.de/Content/DE/Mitschrift/Pressekonferenzen/2014/02/2014-02-04-merkel-erdogan.html, 15.01.2016.

Pressestatements von Bundeskanzlerin Angela Merkel und dem Ministerpräsidenten der Türkei, Recep Tayyip Erdoğan, 31.10.2012, http://www.bundeskanzlerin.de/ContentArchiv/DE/Archiv17/ Mitschrift/Pressekonferenzen/2012/10/2012-10-31-merkel-erdogan.html, 15.01.2016.

Pressestatements von Bundeskanzlerin Merkel und dem türkischen Ministerpräsidenten Erdoğan, 9.10.2010, http://www.bundeskanzlerin.de/ContentArchiv/DE/Archiv17/Mitschrift/Pressekonferenzen/2010/10/2010-10-09-pk-bk-erdogan.html, 15.01.2016.

Pressestatements von Bundeskanzlerin Merkel und dem türkischen Präsidenten Erdoğan am 18. Oktober 2015 in Istanbul, 18.10.2015, http://www.bundeskanzlerin.de/Content/DE/Mitschrift/Pressekonferenzen/2015/10/2015-10-19-merkel-erdogan.html, 15.01.2016.

Privilegierte Partnerschaft. Die europäische Perspektive für die Türkei Beschluss der Präsidien der Christlich Demokratischen Union und der Christlich-Sozialen Union am 7. März 2004, http://www.jostmeier.de/downloads/beschlusstuerkei.pdf, 15.01.2016.

Rada Stowarzyszenia UE-Turcja, 18.05.2015, http://www.consilium.europa.eu/pl/press/press-releases/2015/05/18-eu-turkey-association-council/, 15.01.2016. 
Rede der Bundeskanzlerin beim Deutsch-Türkischen Wirtschaftsforum, 30.03.2010, http://www.bundeskanzlerin.de/ContentArchiv/DE/Archiv17/Reden/2010/03/2010-03-30-merkel-istanbuldeutsch-t\%C3\%BCrkisches-wirtschaftsforum.html, 15.01.2016.

Rede von Bundeskanzlerin Dr. Angela Merkel beim internationalen Symposium „Integration durch Bildung" der Vodafone Stiftung Deutschland und der Beauftragten der Bundesregierung für Migration, Flüchtlinge und Integration am 16. Oktober 2007 in Berlin, Bulletin 109-3, 16.10.2007, https://www.bundesregierung.de/Content/DE/Bulletin/2001_2007/2007/10/1093-bk-symposium.html, 15.01.2016.

Rede von Bundeskanzlerin Dr. Angela Merkel zur Eröffnung des Internationalen Bertelsmann Forums ,, Die Zukunft der Europäischen Union” am 22. September 2006 in Berlin, Bulletin 90-1, 24.09.2006, https://www.bundesregierung.de/Content/DE/Bulletin/2001_2007/2006/09/901-bk-bertelsmann.html, 15.01.2016.

Rede von Bundeskanzlerin Dr. Angela Merkel auf der 41. Kommandeurtagung der Bundeswehr am 10. März 2008 in Berlin, Bulletin 23-2, 11.03.2008, https://www.bundesregierung.de/Content/DE/Bulletin/2008/03/23-2-bk-kommandeur.html, 15.01.2016.

Rede von Bundeskanzlerin Dr. Angela Merkel auf der Veranstaltung der Deutschen Atlantischen Gesellschaft e.V. im Rahmen der 54. Generalversammlung der Atlantic Treaty Association am 10. November 2008 in Berlin, Bulletin 118-3, 10.11.2008, https://www.bundesregierung. de/Content/DE/Bulletin/2008/11/118-3-bkin-gv.html, 15.01.2016.

Rede von Bundeskanzlerin Dr. Angela Merkel beim Festakt ,,60 Jahre Nordrhein-Westfalen” am 25. Oktober 2006 in Düsseldorf, Bulletin 106-3, 25.10.2006, https://www.bundesregierung.de/ Content/DE/Bulletin/2001_2007/2006/10/106-3-bkin-nrw.html, 15.01.2016.

Rede von Bundeskanzlerin Dr. Angela Merkel im Rahmen einer Vortragsveranstaltung der Deutschen Gesellschaft für Auswärtige Politik am 8. November 2006 in Berlin, Bulletin 112-2, 8.11.2006, https://www.bundesregierung.de/Content/DE/Bulletin/2001_2007/2006/11/1122-bkin-europapolitik.html, 15.01.2016.

Rede von Bundeskanzlerin Dr. Angela Merkel zum zehnten Jubiläum des TV-Senders „Euro D” am 13. September 2006 in Mörfelden, Bulletin 82-1, 13.09.2006, https://www.bundesregierung. de/Content/DE/Bulletin/2001_2007/2006/09/82-1-bkin-tv-sender.html, 15.01.2016.

Rede von Bundeskanzlerin Dr. Angela Merkel zur Eröffnung des Türkisch-Deutschen Wirtschaftskongresses am 26. Mai 2006 in Berlin, Bulletin 53-3, 26.05.2006, https://www.bundesregierung. de/Content/DE/Bulletin/2001_2007/2006/05/2006-05-26-rede-von-bundeskanzlerin-drangela-merkel-zur-eroeffnung-des-tuerkisch-deutschen-wirtschaf.html?nn=392138\#Start, 15.01.2016.

Rede von Bundeskanzlerin Merkel zum Festakt „,25 Jahre Deutsche Einheit - 25 Jahre SachsenAnhalt" am 1. Oktober 2015 in Halle (Saale), 1.10.2015, http://www.bundeskanzlerin.de/ Content/DE/Rede/2015/10/2015-10-01-rede-bkin-halle.html, 15.01.2016.

Regierungserklärung von Bundeskanzlerin Dr. Angela Merkel vor dem Deutschen Bundestag am 30. November 2005 in Berlin, Bulletin 93-1, 30.11.2005, https://www.bundesregierung.de/Content/DE/Bulletin/2001_2007/2005/11/2005-11-30-regierungserklaerung-von-bundeskanzlerin-dr-angela-merkel-vor-dem-deutschen-bundestag-.html, 15.01.2016.

Regierungserklärung von Bundeskanzlerin Dr. Angela Merkel zum Europäischen Rat in Brüssel am 14./15. Dezember und zur bevorstehenden deutschen Präsidentschaft im Rat der Europäischen Union und in der G 8 vor dem Deutschen Bundestag am 14. Dezember 2006 in Berlin, Bulletin 128-1, 14.12.2006, https://www.bundesregierung.de/Content/DE/Bulletin/2001_2007/2006/12/128-1-bk-bt.html, 15.01.2016.

Regierungserklärung von Bundeskanzlerin Dr. Angela Merkel zur Europapolitik vor dem Deutschen Bundestag am 11. Mai 2006 in Berlin, 11.05.2006, https://www.bundesregierung.de/Content/ DE/Bulletin/2001_2007/2006/05/2006-05-11-regierungserklaerung-von-bundeskanzlerindr-angela-merkel-zur-europapolitik-vor-dem-deutschen-.html, 15.01.2016. 
Regierungserklärung von Bundeskanzlerin Merkel, 16. Dezember 2015, Berlin, 16.12.2015, http://www.bundeskanzlerin.de/Content/DE/Regierungserklaerung/2015/2015-12-17-regierungserklaerung.html.

Roadmap towards a visa-free regime with Turkey (2013), http://ec.europa.eu/dgs/home-affairs/whatis-new/news/news/docs/20131216-roadmap_towards_the_visa-free_regime_with_turkey_ en.pdf, 15.01.2016.

Schlussfolgerungen des Vorsitzes, 12. und 13. Dezember 1997, http://www.consilium.europa.eu/pl/ european-council/conclusions/1993-2003/, 15.01.2016.

Strategia rozszerzenia i najważniejsze wyzwania w latach 2014-2015, Bruksela, dnia 8.10.2014 r, COM (2014) 700 final, http://ec.europa.eu/enlargement/pdf/key_documents/2014/20141008strategy-paper_pl.pdf, 15.01.2016.

Szczyt przywódców UE z Turcja, 29.11.2015 - Oświadczenie UE-Turcja, 870/15, 29.11.2015, http://www.consilium.europa.eu/pl/press/press-releases/2015/11/29-eu-turkey-meetingstatement/, 15.01.2016.

Turcja. Stan negocjacji. Posiedzenia konferencji akcesyjnej (2015), http://www.consilium.europa.eu/ $\mathrm{pl} /$ policies/enlargement/turkey/, 15.01.2016.

Türkei-Reise der Bundeskanzlerin vom 5. bis 6. Oktober 2006 - Rede von Bundeskanzlerin Dr. Angela Merkelauf dem Deutsch-Türkischen Wirtschaftsforum am 6. Oktober 2006 in Istanbul, Bulletin 97-2, 6.10.2006, https://www.bundesregierung.de/Content/DE/Bulletin/2001_2007/2006/10/97-2-bkin-tuerkei-reise.html, 15.01.2016.

Turkey 2008 Progress Report, Brussels, 5.11.2008, SEC (2008) 2699, http://ec.europa.eu/enlarge$\mathrm{ment} / \mathrm{pdf} /$ press_corner/key-documents/reports_nov_2008/turkey_progress_report_en.pdf, 15.01.2016.

Turkey 2009 Progress Report, Brussels, 14.10.2009, SEC (2009) 1334, http://ec.europa.eu/enlargement/pdf/key_documents/2009/tr_rapport_2009_en.pdf.

Turkey 2015 Report, Brussels, 10.11.2015, SWD (2015) 216 final, http://ec.europa.eu/enlargement/ pdf/key_documents/2015/20151110_report_turkey.pdf, 15.01.2016.

Turkey Progress Report 2014, COM (2014) 700 final, 8.10.2014, http://ec.europa.eu/enlargement/ pdf/key_documents/2014/20141008-turkey-progress-report_en.pdf, 15.01.2016.

Umowa między Uniq Europejskq a Republika Turcji o readmisji osób przebywajacych nielegalnie, Dz. U. UE L 134/3, 7.05.2014, http://eur-lex.europa.eu/legal-content/PL/TXT/PDF/?uri$=$ CELEX:22014A0507(01)\& from=PL, 15.01.2016.

Zięba A. (2010), Rola Niemiec w rozszerzaniu Unii Europejskiej, Warszawa.

1999 Regular Report from the Commission on Turkey's Progress Towards Accession, Turkey-Regular Report - 13/10/99, http://ec.europa.eu/enlargement/archives/pdf/key_documents/1999/ turkey_en.pdf, 15.01.2016.

Keese Ch. (2004), Rückschlag für die Union, „Die Welt”, 19.10.2004.

Schiltz Ch. (2006), Ankara soll Hafen und Flughafen schnell öffnen, „Die Welt”, 14.12.2006.

Schlötzer Ch. (2010), Angela Merkel stößt bei Besuch auf Skepsis. Türkei lehnt „privilegierte Partnerschaft” mit EU ab, „Süddeutsche Zeitung”, 19.05.2010.

Wieliński B. T. (2010), Turcja chtodna dla Merkel, „Gazeta Wyborcza”, 30.03.2010.

Die EU steuert auf eine Einigung zu (2006), „Die Welt”, 12.12.2006.

Merkel and Erdogan Reconcile After Turkish EU Criticism, 16.04.2007, „Deutsche Welle”, http:// www.dw.com/en/merkel-and-erdogan-reconcile-after-turkish-eu-criticism/a-2443800, 15.01.2016.

„Privilegierte Partnerschaft”. Merkel macht Stimmung gegen EU-Beitritt der Türkei (2004), „Frankfurter Allgemeine Zeitung", 16.09.2004.

Turecki premier chce tureckich szkół w Niemczech (2010), „Gazeta Wyborcza”, 26.03.2010. 
Türkei-Beitritt: EU will Verhandlungen mit Ankara teilweise aussetzen, „Frankfurter Allgemeine Zeitung", 6.12.2006.

Türkei-Verhandlungen Ultimatum nein, Bericht unbedingt (2006), „Süddeutsche Zeitung”, 6.12.2006.

Türkischer Staatspräsident Gül fordert Integration und lobt Özil, 16.10.2010, „Focus Online”, http:// www.focus.de/politik/deutschland/tuerkischer-staatspraesident-guel-fordert-integrationund-lobt-oezil_aid_562699.html, 15.01.2016.

\section{Streszczenie}

Celem artykułu jest przedstawienie stanowiska Angeli Merkel wobec członkostwa Turcji w Unii Europejskiej w latach 2005-2015. Podzielony został na 6 części, które przybliżają historię stosunków unijno-tureckich oraz najczęściej pojawiające się kwestie podejmowane przez kanclerz w związku z tureckimi staraniami o akcesję. Autorka zdaje sobie sprawę, iż nie przedstawiła całego wachlarza zagadnień związanych z staraniami o członkostwo tegoż państwa, niemniej zarysowała ważne kwestie, które najbardziej wpłynęły na postawę A. Merkel w ostatnich 10 latach.

Słowa kluczowe: Angela Merkel, Unia Europejska, Turcja, rozszerzenie, integracja

\section{Angela Merkel's approach to the integration of Turkey and the European Union from 2005-2015}

\section{Summary}

The aim of the article is to present the position of Angela Merkel to Turkey's membership in the European Union in years 2005-2015. It has been divided into 6 parts, which introduces the history of relations between the EU and Turkey, and Chancellor's most pronounced concerns in connection with the efforts of Turkish accession. The author realizes that she did not present the whole range of issues related to the Turkey's efforts, but outlined the important issues that influenced the most Angela Merkel's attitude in the past 10 years.

Key words: Angela Merkel, European Union, Turkey, Enlargement, integration 
